\title{
WOMEN-TRANSLATORS IN RUSSIA ${ }^{1}$
}

\author{
Sergey Tyulenev \\ University of Cambridge
}

\begin{abstract}
The paper considers the history of women's involvement in translation in Russia. The emphasis is laid on social issues of women translators' work. The main problems discussed are as follows: How have women contributed to social and literary processes? To what extent were translational activities of women different and/or separate from those of men? Women participated in all major social processes in Russian and Soviet history. From the eighteenth century onwards to the present day, they have been involved in translational work and other types of social-systemic transfer (primarily from the West). Women played their role of translators in the same spheres where men did.
\end{abstract}

\section{Résumé}

Larticle traite du rôle des traductrices dans l'histoire de la Russie du XVIIIe et du XIXe siècles, l'Union Sovietique et la Russie d'aujourd'hui. Laccent dans l'article est mis sur l'aspect social du travail des traductrices. Les questions principales qui sont considerées sont les suivantes: Quelle est la contribution des femmes-traductrices au processus social des transfers de la connaissance européenne en Russie ? Quelle est la différence entre les activités liées à la traduction entre les femmes et les hommes ? Est-ce possible de regarder la traduction faite par les femmes comme un phénomène social indépendant de l'histoire de la traduction générale en Russie ? Larticle suggère que la traduction pratiquée par les femmes est intégrée dans le même processus social que celle pratiquée par les hommes.

Keywords: Women. Translation. History. Russia. Soviet Union.

Mots clés: Femmes. Traduction. Histoire. Russie. Union Soviétique.

1. I would like to thank Dr Natal'ia Pushkareva and Dr Frank Runcie for their help and valuable suggestions. 

Gamètes mâles et femelles se fondent ensemble dans l'oeuf...

Il est abstrait de prétendre les scinder.

Simone de Beauvoir

\section{Introduction}

\subsection{Beware of Extremes}

If the studies of Russian women (SRW) are a scholarly trend in statu nascendi (Pushkareva 1997: xiii, 4; 2008: 226), the studies of Russian women-translators are not more than an embryo: ${ }^{2}$ one encounters individual articles but no coherent study exists. A rare exception is Rosslyn 2000, portraying Russian women-translators from 1763 to 1825 . Wendy Rosslyn does not limit herself to only discovering lost names but analyzes social conditions and effects of women translators' work. The thrust of my paper is along the same lines. The focus is on women-translators' social involvements. More specifically, the main question, which I will attempt to answer, is: How did women contribute to social and literary processes? I will also consider to what extent translational activities of women were different and/or separate from those of men. I will limit myself to women-translators predominantly from foreign languages into Russian. The following overview does not claim to provide a list of women-translators or a gallery of their portraits. ${ }^{3}$ I will organize my presentation

2. SRW should be distinguished from collecting historical evidence about or by women, a necessary, yet ancillary stage. The beginning of looking for historical documents about women can be traced to the late eighteenth-early nineteenth centuries in Russia. Only in the late 1980s, however, were attempts made to synthesize the collected materials (Pushkareva 2002: 11, 33; see also the bibliography there). Among the first fragmentary materials about women-translators are Daniil Mordovtsev's Russkie zhenshchiny novogo vremeni (Russian Women of the New Time; Saint-Petersburg, 1874) and Nikolai Golitsyn's Bibliograficheskii slovar' russkikh pisatel'nits: 1759-1859 (Bibliographical Dictionary of Russian Women-Writers: 1759-1859; Saint Petersburg, 1889). Goepfert and Fainshtein 1998 and 1999 and Uchenova 1989 furnish examples of collecting actual texts and translations by women-translators of the eighteenth-early nineteenth centuries.

3. Some biographical information on women-translators can be found in LRZ; Kalinnikov 1997-2009; Panchenko 1988, 1999; Pietrow-Ennker 2005; Pushkareva 1997; Uchenova 
of women's translation chronologically with the emphasis on major types and patterns of social activities in which women-translators took part.

To begin, a few methodological clarifications are called for. Views on women range from considering women "equal with men before the law" (Kostomarov qtd. in Pushkareva 2002: 15) to suspecting misogynist motives even where there were none. ${ }^{4}$ One should beware of both extremes. The goal of women studies as a scholarly discipline is to recover at least some names for both Russian and world culture and to understand women's social involvements (Goepfert and Fainshtein 1998: 6; Rosslyn 2000: 7).

Another problem to be touched upon is that sociological studies show that some women far from being victims, helped to uphold the patriarchal social order (Aristarkhova 1995; Bisha et al. 2002: 11-12). An unprejudiced presentation of women as writers shows that women were not so different in certain aspects as compared to men: there were talented poets and writers among women and men as well as there were poetasters and scribblers. The dynamics of the relationship between men and women in literature is quite complex and one should avoid simplistic generalizations. Some men-writers, notably Derzhavin, Kheraskov, Karamzin, helped women-writers to find their place in literature. Women cooperated with men, even in the organizations where they tried to do everything by themselves (Stasov 1899; Pietrow-Ennker 2005: 191). At some periods, boundaries were drawn between women and men; at other periods, the boundary went not so much between the sexes as

1989, etc. See also a bibliographical essay by June Pachuta Farris in Norton and Gheith 2001: 249-279.

4. In her discussion on how women were represented in Russian medieval literature, Rosalind McKenzie writes that the mother of a highly revered Kievan Rus' saint, Feodosii Pecherskii, is portrayed in the saint's hagiographical life description "as an overpoweringly strong character of the negative type" representing "the worst apprehensions of the clergy about women" (2002: 23). Feodosii's mother is indeed compared to a man, but McKenzie fails to appreciate the fact that the cruel woman is compared to a man; thereby a man is made the typical example of cruelty. It should also be noted that both parents were against his intense Christian meekness (Sevcenko 1992: 37). Feodosii's father did not take a more active part in persuading or forcing Feodosii to turn away from his monastic inclinations only because he died when Feodosii was thirteen years of age. McKenzie's conclusion that "the Church is also left with an unforgettable portrait of a woman who acts directly against the Christian forces of Good" seems somewhat ill grounded if one recalls Russian women-saints or the life story about a famous saint of the Catholic Church (if that would count)—Francisco of Assisi. There, it is Francisco's father who is shown to be evil, whereas his mother was kind and supporting (Celano 2000: 16-19). Would it be justifiable to conclude that, deplorably, the Church is left with an unforgettable portrait of a man who acted directly against the Christian forces of Good? 
between significant and less significant, talented and less talented authors. Presenting women in opposition to men may lead to an idealistic portrayal of the relations between women, but women could be prejudiced against each other, as was the case with Evdokiia Rostopchina and Karolina Pavlova. We know about conflicts even within one group of women, with the same goals within one and the same enterprise (Stasov 1899: 127).

\subsection{Translation}

The same complex dynamics of women's involvement in translational processes is observed in the history of Russia. Yet translational activities of women in Russia have never been a primary scholarly focus. Such investigation would fall into the category of studies of women in professions (Norton and Gheith 2001: 20; DenBeste 2008). Yet a caveat is required. One can speak about women as professional translators, that is, working for remuneration, by and large starting only from the nineteenth century. One can speak about documented evidence of women's involvement in translation, whether professionally or non-professionally (often simply for pleasure), only from the eighteenth century onwards. In this, as in many other respects, Russian translators were in much the same situation as women-translators elsewhere and students of other regions will not fail to notice similarities, yet, my focus being not comparative studies, I will concentrate on Russia exclusively.

Women's translation work should be considered in the context of the literary scene in Russia. One can separate them from men only with great care and with a clear goal in mind. Heinz von Foerster warned against imposing systemic description principles on objects of scientific study, which do not manifest any properties of systems (1981: 8-9). While there were translating women, in Russian history there has never been such a thing as women's translation as a separate social and professional (sub)system. ${ }^{5}$ One can study the history of women's involvement in the 'overall' literary or non-literary translational processes but not women's translation as something separate from translation practiced by men.

One more point to be made concerns the discrimination between writing and translation. Often, it is not at all clear where translation stops and original

5. Cf.: "[W]omen's journalistic work cannot fully be understood in a separate context, since there is no tradition of women's journalism that can be extracted from the larger context of Russian journalism. The counterstatement is also true: journalism by men did not exist separately from journalism by women [...]" (Norton and Gheith 2001: 17-18). The same holds true for women's translation. 
creative writing begins. Itamar Even-Zohar warned against artificially divorcing translation (verbal rendering of text in one linguistic medium into another) from a broader notion of transfer understood as the rendering of nonverbal phenomena from one system into another (1990: 73-74). As will be shown below, women actively participated in the westernization of Russia in the eighteenth century. Their writings (as well as men's at the time) thrived on Western European themes, motifs, cultural notions and values, yet not all of their translations were renderings of concrete foreign texts and some of their transfers were not verbal at all. Would all these writings and transfers qualify as translations? In the present paper, I answer this question with an emphatic 'yes' because the absolute majority of semiotically broadly conceived texts, imbued with Western European culture, can be described as translationtransfer: they rendered something from outside into the social system (the Russian empire). By comparing any westernizing effort with the position assumed by Liubov' Iartseva (1794/97-1876) it would be easier to appreciate such categorization. She was an exception that proved the rule: she was "the first author of original Russian literature for children that was not influenced by West European models... [Throughout her career she] remained true to her main principles: keeping to original narratives and avoiding translations" (LRZ: 249-250). To push my point still further, our understanding of translation can be broadened to include the types of transfer, which go beyond the verbum-based activities. For example, Ekaterina Avdeeva (1789-1865) did not translate texts from one language into another, yet she did transfer at least one Western European phenomenon into Russia: in 1863-1865 at her estate near the city of Novgorod, she established an agricultural enterprise modeled on contemporary English farms as a type of "rational agriculture" without serf labor (LRZ: 42). Such transfer can be analyzed as a type of translation qua systemic boundary phenomenon (see my discussion of the notion in Tyulenev 2009a: 158-159).

A few words on periodization are required. The history of women in Russia is usually divided into the following periods. Ancient Russian history is the period of Christian-based patriarchy when women's role in social life was significantly less visible than after the beginning of Petrine westernization in the early eighteenth century (Pushkareva 1997: 121; Clements, Engel and Worobec 1991). Petrine reforms legally and socially strengthened the position of women in the family and in the society. Women also enjoyed easier access to education. The second historical watershed was the Great Reforms of the mid-nineteenth century. The Great Reforms further encouraged women to take part in social and economic life. Yet disappointment with the limited 
scope of the Great Reforms inspired some women to engage in struggles for their rights (Bisha et al. 2002: 12-13). In the Soviet (1917-1991) and the postSoviet periods, education became general, and women were socially (extrafamilially) much more active.

Sometimes, especially as far as earlier periods are concerned, research cannot claim to be more than a conjecture because of the scarcity of surviving evidence. Sometimes researchers are lucky to have only the name of the womanwriter/translator. For instance, we know about Mariia Zubova (?1749-1799), a poet, translator and song writer, only that she translated from French, yet her translations did not survive (LRZ: 260-261). About Aleksandra Murzina it is only known that in 1799 she published a collection, Blooming Rose or Works in Prose and Verse. Sometimes only cryptograms and no signature at all is all what is left from women-writers/translators (Goepfert and Fainshtein 1998: 6). That is why the uniformity—name, surname, dates of birth and death—in introducing women is not always observed.

\section{Kulturträger}

\subsection{In the Highest Places}

All we know about ancient Rus' is that some women from privileged classes gained a high degree of education and might have been involved in translational activities. Such was the twelfth century saint Evfrosiniia of Polotsk, who wrote books in her own hand and produced manuscripts (Evfrosiniia 2006: 10; Mel'nikov 1997: 28-29). Uladzimir Arlou goes as far as to say that she did translate on the evidence that she corresponded with Byzantium (1998: 88). Another female, saint Evfrosiniia of Suzdal', knew works by Greek and Latin authors (Pushkareva 1989: 39-40). Yet we cannot be absolutely sure if these women or their female contemporaries translated.

The approach of recent Russian history clears up the mist of hoary antiquity. In the late seventeenth-eighteenth centuries, the beginning of the westernization of Russia, the process of the reformation of Russia along Western European lines, opened access to education and literary activities for women from the social elite. Some women remained traditional in their behavior and played largely a "decorative" part in society. But there were well-educated women who assumed a more active social position. The beginnings of identifiable and documented history of women-translators start in Russia at its highest social stratum. At that point, women were involved in translational activities not only for their own pleasure. Whether knowingly or not, they participated in renegotiating the state ideological discourse (Tyulenev 2009b). 
Among the first women who might have been involved in translational activities in the period of the westernization of Russian were two Princesses: Peter the Great's stepsister Sof'ia (1657-1704) and his sister Natal'ia (16731716). If they did not themselves translate, both of them at least commissioned translations of foreign plays for court theatres (Mokul'skii 1929-1939; Komarov, Komarova 1997-2004; Poulton 2002: 23-24; Rulin 1924: 234; Pushkareva 1997: 125).

As reforms gained momentum, "the number of educated, creative, active, and energetic women in eighteenth-century Russia grew remarkably" (Pushkareva 1997: 153; also Likhacheva 1890). ${ }^{6}$ The role of one of such amateur female translator, Empress Catherine the Great (1729-1796), cannot be overestimated. When Catherine translated, for example Jean Marmontel's Belisarius and a selection of articles from the French Encyclopedia, she meant to set up an example for her subjects to emulate. She also initiated The Society Striving for the Translation of Foreign Books. In its five years of existence, the Society put out as many as 112 translations and worked on yet another 129 of Western-European classics and contemporary writers (Whittaker 2003: 58).

Catherine's cultural aide, the Director of Saint-Petersburg Academy of Arts and Sciences and President of Russian Academy of Sciences, Ekaterina (Vorontsova-) Dashkova (1743-1810) was also a writer and a translator (Pushkareva 1997: 148; Smagina 2006). She translated from French and English (Voltaire, Helvétius, Hume) (Vorontsov-Dashkov 1996: 42-43, 77; LRZ: 143). She published at least two journals largely based on translations. In her capacity as President of the Academy of Sciences, she commissioned translations of scientific and scholarly literature and manuals

6. Tsarina Praskov'ia (1664-1723), the wife of Peter the Great's co-tsar Ivan V (1682-1696), was a very interesting woman who exemplifies a transitory figure between pre- and Petrine Russia. By her upbringing she was an old Muscovite woman, yet she was so loyal to Peter that she was always among the first to put Peter's reforms to practice. She invited Johann Ostermann, one of Peter's close aides Heinrich Ostermann's brother, to give her daughters a non-Muscovite education, featuring French and German languages, dancing, etc. Praskov'ia moved to Peter's newly built Saint-Petersburg despite her suffering from its dismal climate; she participated in the assemblies organized by Peter after the Western European fashion; etc. She combined in herself a "pre-Petrine woman in her superstitions, prophecies and bigotry; and a Petersburg woman of the reformed epoch in her ability to get along with the contemporary spirit, in educating her children, and passing her time" (Mikhail Semevskii in Leventer 1974: 20). She played the role of a Kulturträger. She did not initiate the reforms, yet she reinforced them and thereby cemented them. Or one might say, she did not initiate the translation of Western European values into Russia, yet she did translate them by practicing them. As we are going to see in what follows, many women-translators played a similar role. 
(Vorontsov-Dashkov 1996: 106-107). She introduced translation into the curriculum of the Gymnasium of Saint-Petersburg Academy of Sciences (Vorontsov-Dashkov 1996: 80; Dashkova SPbGU). Not only was Dashkova a translator herself but also she should be credited as one of the first Russian translation educators.

Both Catherine the Great and Dashkova translated not only verbal texts but also participated in large-scale transfers of Western European knowledge and values. While preparing her Instructions to the Legal Commission (1766; final version 1768), Catherine the Great drew heavily on ideas of Western European authorities in legal theory. In her own words, Montesquieu's De l'Esprit des lois was Catherine's "prayer-book" and out of 655 articles of her Instructions, as many as 294 were direct transfers of Montesquieu's ideas (Poulton 2002: 52-53, endnotes 8, 9 on pp. 65-66). ${ }^{7}$ Ekaterina Dashkova's transfers of Western European cultural phenomena can be illustrated by her implementation of educational and administrative principles that she had observed at European universities (Vorontsov-Dashkov 1996: 81-82, 84-85, 87).

The four women just discussed belonged to the highest level of the state hierarchy in Russia. They exemplify well the role women played in reinforcing Petrine and post-Petrine reforms aiming at the westernization of Russia. ${ }^{8}$

7. In Pavlenko 1999: 114-115, the figures are different (out of 526 articles of the Instructions, 245 are traced to Montesquieu), but this does not change the essence of the matter. Catherine also used some entries from the French Encyclopaedia; 106 articles apparently came from the book Dei Delitti e Delle Pene (On Crimes and Punishments) by Cesare Beccaria-Bonesana, an Italian, a major author in criminology of the eighteenth century. Catherine also made use of works by the Germans Johann Jakob Friedrich Bielfeld and Johann Heinrich Gottlob Justi and by the Englishman William Blackstone.

8. At least one more royal woman-translator can also be mentioned. Catherine the Great's son, Russian Emperor Pavel I (1796-1801) and his wife Mariia Fedorovna had a daughter, Aleksandra (1783-1801), sister of Emperors Alexander I (1801-1825) and Nicholas I (1825-1855). She was the first wife of Austrian Erzherzog Joseph (1776-1847). In 1796, when Aleksandra was thirteen years of age she published two translations from French in the magazine The Muses (Kalinnikov 1997-2009). Yet her translation output was too limited and had little in common with activities of national importance undertaken by Sof'ia, Natal'ia, Catherine or Dashkova. 


\subsection{The Grassroots}

Ты вкусы всех, мой друг, и чувства съединяешь, Но славу всю другим охотно разделяешь.

Аноним. Надпись моему другу, любителю литературы, $1798^{\circ}$

From the late eighteenth century onwards the number of women involved in translation grew by leaps and bounds. However, even though without royal connections and professional titles, the majority of women-writers in eighteenth-century and early nineteenth-century Russia still belonged to social elite. They were born into literary families or published their works in journals edited by their male relatives or protectors. All of them were fluent in French, German or other modern as well as classical languages. Some of them, like Elizaveta Kul'man (1808-1825), who mastered more than ten foreign languages, translated both from and into them. What is important is that, on the one hand, all writing women were a product of the westernization of Russia and, on the other, they significantly contributed to its furtherance.

Translation was practiced in Russia without formal education until the mid-twentieth century. That is why translation was one of the earliest socially recognized women's public occupations. ${ }^{10}$ The first women who translated and published their works in the late eighteenth century translated mainly belles-lettres works of the neo-classical, Sentimentalist and Romantic trends (Hammarberg 2003 and 2007). Whatever we know of their works is what found its way into literary magazines or, as in the case of Mar'ia Pospelova (17801805), was even published as a separate collection. Elizaveta Kheraskova

9. "My friend, you bring together all people's tastes and feelings / But you give your glory willingly to others." (From an anonymous Russian poem "A Poem for My Friend, a Lover of Literature," 1798). All translations, unless marked otherwise, are mine-S.T.

10. This was in contrast with medicine, pharmacy, dentistry and midwifery, which Russian women could formally study only by the end of the nineteenth century. It may not be possible to call translation a profession in a modern sense because translators, both men and women, did not form a distinctive body of specialized knowledge, which would be acquired by special training, and institutionally regulated practice. But the applicability of the term 'profession' has to be reconsidered in gender studies: "In Russia, as in most places in the world in the late nineteenth century, women often became involved in charity work, in sponsorship of the arts, in literary salons, and in other unpaid pseudo professional labor. According to current academic definitions, this type of work cannot be considered professional work because it is not paid and is not regulated by professional bodies. Nonetheless, it sometimes very closely resembled paid professional work" (DenBeste 2008: 89-90). Taking DenBeste's argumentation into account, in the present paper I will use the terms 'profession' and 'occupation' interchangeably. 
(1737-1809), Ekaterina Urusova (1747-?), Aleksandra (?-1846) and Natal'ia (?) Magnitskaia, Anastas'ia (?) and Ekaterina (?-1841) Svin'ina were among the first women-translators. They paved the way that many women in the nineteenth and twentieth centuries would tread.

In the eighteenth century, writing was still a frowned-upon activity for aristocrats of both sexes, but especially for women, ${ }^{11}$ hence women-translators and writers often published under their initials, pseudonyms or without signatures at all. Therefore, some publications allow more than one attribution (LRZ: 630). Yet the turn of the nineteenth century witnessed the appearance of professional female literary work. Anna Bunina (1774-1828) was the first Russian woman who made her living by writing and translating from Greek and French (Vowles 2002: 66-68). In her first collection of poetry, The Inexperienced Muse, translations made up about one-third of the poems (Andrew 2001: 56). In 1819-1821, she published a three-volume collection of her works-both translations and her own poetry. Her last publication was also a translation: her version of Hugh Blair's Moral and Philosophical Conversations (LRZ: 108-109). Bunina also provides one of the first examples of publishing translations outside of literary journals.

Women translated for the theatre. Elizaveta Titova (1780-?) published a version of Mme. de Genlis's one-act comedy, L'Aveugle de Spa (1797). Varvara Miklashevich (1786-1846) made her literary début with Russian versions of two French one-act comedies, both performed at the Aleksandrinskii Theater in Saint-Petersburg. Pelageia Vel'iasheva-Volyntseva (1773-1810) also translated plays from French. Another prolific woman-translator Mar'ia Sushkova (1752-1803) rendered as many as five French comedies and operas into Russian, four of which were performed and published (O'Malley 2007: 19).

In the early eighteenth century, women participated in introducing the fashionable Gothic literary trend, thereby contributing to enriching the national literature's repertoire of genres. Mar'ia Arbuzova and, possibly, "g-zha" (Madam) Kalashnikova (?) and Nadezhda Levshina (?) took part in the

11. When a poem by Evdokiia Rostopchina was published in 1831, the young girl-poet was punished, because "it was inappropriate for a noble girl to write poetry, let alone publish it. That is why Evdokiia Petrovna did not publish any more of her poems until marriage" (Rostopchina 1910: 4). When she finally started publishing her poetry, she did it under the signature "gr. R-na" which was an abbreviation from "grafinia Rostopchina" (Countess Rostopchina). Her prose works first appeared later (in 1838) under the nom de plume Clairvoyante (ibid.: 5). Nadezhda Khvoshchinskaia (1824-1889) and her sisters Sof'ia and Praskov'ia published under pseudonyms: "V. Krestovskii," "Ivan Vesen'ev" and "S. Zimarov" respectively (Bukhshtab 1972: 259-260). These cases were by no means exceptional. 
translation of R. M. Roche's novel Les enfants de l'Abbaye (The Children of the Abbey). The novel in their translation went through two editions: in 1802 and 1824 (Vatsuro 2002: 265). Mariia Izvekova (179?-1830) imitated Gothic fiction in her own writings combining it with Sentimentalist and Romantic features (LRZ: 267-268).

Although my primary focus in the present paper is on women translating from foreign languages and cultures into Russian, it is necessary to mention that they translated into foreign languages as well. For instance, in 1772, Mar'ia Sushkova, who translated not only from Western European languages, but also a poem by Mikhail Kheraskov into French (Le combat de Tzesme) with an appendix on Russian poetry ("avec un discours sur la poèsie russe"). Zinaida Volkonskaia (1789-1862) compiled her Tableau slave du cinquième siècle based on the available historical data about early Slavic culture (LRZ: 726). These were women's contribution to informing Western Europe about Russia.

Translation and imitation of foreign models in the context of the westernization of all spheres of Russian life were an indispensable stage in the history of Russian literature. The foundation was laid for original literary work. In the mid-nineteenth century, in her poem "To Women-Poets" (1845), Elizaveta Shakhova (1822-1899) called herself "the youngest sister of sisters who have gone before" pointing to an established tradition of women's poetry (Vowles 2002: 62).

In the early nineteenth century, women actively participated in literary salons (Andrew 2001: 58). Women-translators and writers found an audience and encouragement in such assemblies. Karolina Pavlova (1810-1894) is probably the best example. She started attending Zinaida Volkonskaia's salons in the 1820s. Volkonskaia as well as other literary figures of the time, no doubt, helped her mature as a writer and translator. Possibly, Volkonskaia or her example inspired Pavlova to translate Russian poetry and plays into French and German (Pavlova 1994). Her translations were praised by European literary figures of the highest caliber, notably Goethe. In the 1840s, Pavlova opened her own literary salon. The baton was passed from one generation to another ${ }^{12}$.

Avdot'ia Glinka (1795-1863) and her husband, Fedor Glinka, played an important role in supporting young talents among women by welcoming them to their Moscow home (Vowles 2002: 64). Avdot'ia Glinka herself

12. Pavlova also translated from Western European languages. Sir W. Scott, T. Campbell, F. Schiller, F. Rueckert were among the authors whom she translated. 
was a distinguished translator. She specialized in German poets. In 1832, she became famous by translating Schiller's ballad "Das Lied von der Glocke." Later in her career, she also translated the poetry of Goethe and Herder. She was elected an honorary member of Moscow University's Society of Lovers of Russian Literature for her translations of Schiller's poetry published in 1859.

In the second quarter of the nineteenth century, women continued to participate in literary life by publishing in journals, especially in The Muscovite, where Ekaterina Rostopchina (1776-1859), Karolina Pavlova, Avdot'ia Glinka, Iuliia Zhadovskaia (1824-1883) published their works on a regular basis. A sizable part of these publications was translations from classical languages and vernaculars (Bukhshtab 1972: 9). These translators, like Elizaveta Shakhova, should also be seen as heiresses of their "sisters who had gone before."

\subsection{Transferors}

In the eighteenth and nineteenth centuries, Russian literature did not simply appropriate literary forms, but learned from and even rivaled source literary traditions. Russian writers borrowed and developed elements of Western European culture on the basis of their own individuality (Sazonova 2000: 45, 48). For example, Natal'ia Magnitskaia's "Ode. From Anacreon" has little in common with her contemporary Nikolai L'vov's version of the same Anacreontic Ode IV. The latter follows the original quite closely, whereas Magnitskaia's version is rather a variation on the theme of the second half of its original. Her translation follows the contemporary Western European tradition of imitating Anacreon and even creating 'national' Anacreontic poetic schools (Gukovskii 1927: 121-122; also Delboulle 1891). Magnitskaia wittily develops and even refines her original. The original only says that odored tombs cannot avail the dead, that there is no point in shedding vain libations: the poet wants to receive balms and roses while still alive (Delboulle 1891: 16). Magnitskaia radicalizes this motif and brings it, if somewhat cynically, down to earth. This is evident in the final lines: "By sprinkling my ashes with fragrant dew / You cannot make me drunk. / You'll only make a muddy puddle" (the full text in Russian is available at http://lib.pushkinskijdom.ru/Default.aspx?tabid=5630. accessed on December 9, 2009).

To a greater or lesser degree and in various forms, women's literary works were imbued with Western European imagery. Let us look at some examples. Ekaterina Urusova (1747-?) is categorized as a poet in LRZ (683): she composed two long poems, Polion, or the Enlightened Misanthrope (1774) and Heroic Verses Dedicated to the Muses (1777). In both, she made Western European literature her source of inspiration (Kelly 2002: 38, 44). For example, 
the eponymous protagonist of her mock-epic Polion, a misogynist, is reminiscent of Euripides' Hippolytus. In her Heroic Verses, she declared that Russia got its own Sapphos and de la Suzes and she strived to be one of them. Her reference struck a resonance in society, and Gavriil Derzhavin ironically explained his rejection of a proposed match with Urusova because both of them wrote, so there would be nobody to make the traditional Russian cabbage soup (LRZ: 683).

Ekaterina Kniazhnina (1746-1797), the daughter of Aleksandr Sumarokov, a leading poet of the eighteenth century, authored one of the first elegies published by a woman in Russia (1759). She, thus, participated in establishing elegy as a literary genre in the second half of the eighteenth century.

Indeed, women played an active part in the establishment - 'naturalization' - of a number of literary genres, notably odes, epitaphs, rondeaux, heroic verse, eclogues, etc. For instance, the genre of idyll was brought to Russia from France, and Mar'ia Sushkova was one of the foremost women-translators of idylls (Goepfert and Fainshtein 1998: 109-110). ${ }^{13}$ Literary historians and critics may dismiss writers who did not create masterpieces in these genres as epigones (Gukovskii 1927: 68-69, 101), yet these writers cemented the newly established literary tradition. For example, the ode as a major genre of neo-classical poetry was introduced into Russian literature by Mikhail Lomonosov but later it attracted many female writers, such as Mar'ia Sushkova, Aleksandra and Natal'ia Magnitskaia, Aleksandra Murzina, Anna Bunina, and especially Mar'ia Pospelova. Although only of a limited aesthetic significance, the experiments with odes and with minor genres of neo-classical verse, such as fable and epigram, in the poetic output of these women (as well as of male poets) helped these genres take root in Russian soil.

Evdokiia Rostopchina also drew on Western European literary tradition. Many of her poems opened with epigraphs from Western European poetry by Byron, Heine, Dante, etc. In her own words, from the outset, her writing was inspired by the most prominent authors of her day, especially Schiller and Byron (1910: 4). Her poem André Chénier speaks of her love of this poet's work since childhood (1910: 604-605). As a result, she "befriended his feelings and

13. Sushkova translated not only French idylls. Her translations from English included a monologue from Addison's Cato, Young's Night Thoughts. She also translated from Italian, notably works by Petrarch, and contemporary theatrical works from French. From 1778 to 1819, her translation of Marmontel's novel Les Incas went through four printings amounting to 5000 copies (LRZ: 629). She also translated works by Kheraskov into French. 
his thoughts". This constitutes a prime example of how Western European literary models were introduced into Russian literature.

Turning to prose, similar patterns can be observed of fusing Western European literary tradition with Russian. Countess Natal'ia Golovkina (17691849) published her major novel Elisaveta de $S^{* * *}$ (1802) modeled on such popular eighteenth-century epistolary novel as Richardson's Pamela (1740) (Tosi 2007: 48, 50). Although Golovkina cannot be credited with the introduction of epistolary literary genre into Russian literature, she contributed to its establishing and evolution. Nadezhda Durova (1783-1866) is famous for her original autobiographical notes of the 1812 campaign in her Cavalry Maiden (1836). Durova's style echoes Sterne's Sentimental Journey. Mar'ia Pospelova was known to have worked on a novel in the style of Chateaubriand's Atala.

Another form of transfer-based literary activity is creating sequels to foreign works. Ekaterina Dashkova's comedy Fabian's Wedding is believed to be a sequel of August von Kotzebue's lost comedy Poverty and the Nobility of Soul (Goepfert 1995: 113).

Even what is usually categorized as original literary works of eighteenthand nineteenth-century female authors contains a good deal of characters or names appropriated from Western European literature and mythology. Sometimes such names become "the masks that Russian women used in order to write" (Kelly 2002: 49-50). Among such masks are the Greek poets: modest and yet ambitious Corinna ${ }^{14}$ and Sappho, ${ }^{15}$ viewed as a primarily sentimental figure, as well as the Greek mythological character Niobe, a symbol of the devoted mother and wife. Catherine the Great was called "Northern Minerva" (Sviiasov 2003: 22).

Besides, there were other borrowed classical or Western European characters, names and terms. For example, in a poem by Aleksandra Magnitskaia "Life in the Countryside. To Damon," Orpheus sings in a nearby grove. In her allegory "Beauty and Modesty," the entourage is Greco-Roman with Jupiter on Olympus. Sometimes Western European images even clashed with quintessentially Russian realia, as is the case in Anna Zhukova's (?-1799) poem

14. Corinna is described by Elizaveta Kul'man as follows: "Then a young maiden, / whom gods gave as gifts / Beauty, pleasant voice / And the spirit of a poet, / comes with timid steps..." (Uchenova 1989: 50).

15. Both women (Urusova) and men (Novikov, Kheraskov) writers used Sappho as the symbol of women-poets (Sviiasov 2003: 60-61). This tradition survived into the early twentieth century: the poet Mirra Lokhvitskaia was called "Russian Sappho" (Nikolaev 1996: 440-441). 
"Winter Images." There, in the same poem, the nightingale is referred to as Philomela, yet on their arrival home, travelers sit around the table to sup the hot shchi, Russian cabbage soup. Nothing stopped the apprenticed lyre from appropriating new imagery. And it is the Greek lyre that Russian poets had in their hands now. Aleksandra Magnitskaia wrote that her home bird sang to the sound of her lyre ("On the Death of My Skylark"). She called the Russian poet Kheraskov "bard," and the fruit of her sister's and her own poetic inspiration was referred to by her as "Muse's labor."

The transfer of philosophical and religious ideas and enlightened feminism is another type of transfer. Elizaveta Kheraskova is believed to have been influenced by Masonic ideas (Goepfert 2003). For instance, her "Sonnet" (1761) introduced not only another Western European poetic genre, but also new religious and philosophical motifs. For example, it is striking that among human sufferings, Kheraskova lists our being "subdued by authority." Questioning authority was unusual for Russians of that age, especially for women. It testifies to an emerging worldview. Analyzing another poem by Kheraskova, "Stans" ("Stanza", 1760), where the poet doubts that love is the pinnacle of female existence, Catriona Kelly writes that "Kheraskova's declaration of independence [of the soul from love], while influenced by the Masonic ideas of her husband, is also consonant with enlightened eighteenthcentury feminism, forerunning, in some senses, Mary Wollstonecraft's strictures against the cult of love by women [...]" (2002: 43).

\section{The Great Reforms}

Звание писательницы пока еще контрабанда не у одних нас. Лживый взгляд на женщину осуждает ее на молчание. ...Женщина давно уже приобрела право говорить печатно,- - но как и о чем говорить? вот вопрос, подробное решение которого завело бы нас далеко-далеко... в самую Азию ${ }^{16}$. Vissarion Belinskii, 1843

In this section, I would like to show yet another aspect of Russian womentranslators' contribution to social life. This aspect concerns itself with another radical reformation of Russian social life — the Great Reforms of the 1860s.

16. The idea 'woman writer' is still contraband not only to us. Hypocritical views on women condemn them to silence. ... Women have already gained the right to speak in print, but how and about what? An attempt to answer this question would lead us far away... all the way to Asia... 
Usually, the primary stress is laid on the abolition of serfdom, yet the emancipation of women, that is, their growing participation in a number of social domains beyond the familial, was also of significant consequence for the course of Russian history in the decades to come. The main difference with the previous periods is accessibility of education to women belonging not only to the nobility, but also to other social strata. This brought other social groups of women onto the social arena. Translation, once again, manifests itself as an important means of preparing and, then, carrying out and expanding the Great Reforms as regards women's emancipation, among other things ${ }^{17}$.

\section{1. 'Mothering' Agency}

In this subsection I will touch upon a facet of translators' activity which, perhaps, manifests itself in women's work more conspicuously than in men's. To exemplify this facet, I will turn to the role that Mariia Vernadskaia (née Shigaeva, 1831-1860) played in paving the way for the Great Reforms in the aspect of women's emancipation.

Vernadskaia was steeped in the atmosphere of heated social and political debate that eventually led to the Great Reforms. She was well educated and well read. She was the first Russian woman-economist. Together with her husband, Ivan Vernadskii, she published one of the first political-economic journals in Russia. She contributed articles, book reviews and translations of contemporary Western economic treatises. She was thus one of the first women-translators who went beyond belles-lettres. Vernadskaia's ideal was Elizabeth Blackwell, the first American woman physician, rather than women-writers like George Sand (Rosenholm 2001: 73-74).

Vernadskaia acted as a translator not only when she rendered Western European economic publications into Russian but also when she made contemporary Western European thought available to Russian women, thereby educating them, broadening their horizons and encouraging them to be more socially active. Arja Rosenholm termed the social function, assumed by Vernadskaia, "the mothering agent" (2001: 76). When analyzing women of the late nineteenth-early twentieth centuries in medicine, Michelle DenBeste observes a comparable motivation: "Women came to medicine in a variety of ways but nearly all claimed the desire to improve ordinary people's lives as a primary motivating factor. [...] All [women in medicine] share the desire

17. For example, women-translators, such as Vera Zasulich (1849-1919), would play key roles in introducing Marxism into Russia. Zasulich translated Engels' works into Russian in 1884 (Sidorov 1964: 469). 
to heal people and to help those less fortunate than themselves" (DenBeste 2008: 94). Not every translator is motivated, as Vernadskaia was, by the desire not only to acquaint the target readership with foreign works but also to educate. Even complex economic ideas were presented by Vernadskaia with "young gentry women (often addressed directly by the narrator) unused to reading about political and economic issues" in mind (Rosenholm 2001: 74).

Vernadskaia's adaptation of complex political-economic notions and terminology may be considered not only as inter-, but also intralingual translation: she transferred new knowledge from one linguistic medium into another but also she reformulated new notions within one and the same language.

There were other women who also accomplished the same mission of educating Russian readership by rendering and adapting source texts and cultures. Aleksandra Bykova (née Proskuriakova, 1863-?) authored a number of popular essays on different foreign countries, such as the USA, England, Ireland, France and Italy. Mariia Davidova (1863-?) acquainted Russian readers with the biographies of Mozart, Schumann, and Meyerbeer. Anna ValuevaMunt (1856-1902) addressed her biographies of Columbus, Lincoln, Washington, Franklin and others to children (1882-1893). Elizaveta Vodovozova-Semevskaia's (née Tsevlovskaia, 1844-?) three-volume series The Life of European Nations went through five editions (1875-1907). Zinaida Vengerova (1867-1941) played a significant role in introducing Western European writers to Russia in her articles and numerous translations. ${ }^{18}$ The list is by no means exhaustive. To reiterate, these works were not necessarily translations in the narrow sense — but they transferred (translated) Western European knowledge and cultures into the target system and from one register into another within Russian language.

\subsection{Cooperation}

The Great Reforms of the 1860s granted thousands of women an opportunity to live an active social life (Pietrow-Ennker 2005; Stasov 1899: 118-119). Some of them worked together -in publishing and translating cooperatives.

To be sure, this was not the first time for women to team up to translate. The sisters Magnitskaia together with Ekaterina Shcherbatova (?) and Mariia Boske (?) translated Lettres sur l'Italie by Dupati from French in the late eighteenth century. Yet, this and similar cases were only episodes in the

18. Vengerova also promoted Russian literature in the West by publishing articles or giving public lectures on Russian literature and culture in foreign periodicals and translating Tolstoi into English. 
lives of individual women-translators, incomparable with the organization of women-translators and publishers, such as The Society of Women-Translators (SWT) (1863-1870).

SWT was an organization where only women worked (Stasov 1899: 120128). Mariia Trubnikova (1835-1897) and Nadezhda Stasova (1822-1895) were among the founders of SWT. Altogether SWT employed 27 women. As it had been earlier, in their search for independent work, their command of foreign languages "naturally" led the women to translation. Another motivation was provided by the dissatisfaction with available educational publications. Women did not want to put up with a "lifeless life of ignorance"; they started thinking how to help the situation and began to translate books themselves (Stasov 1899: 118). Once again, women-translators manifested themselves as "mothering agents." The first Society's translation appeared in 1863. It was a collection of Andersen's fairy tales. The translation was made from German by Nadezhda Belozerskaia (1838-?), Aleksandra Markelova (1832-1916), Anna Engel'gardt (1838-1903) and A. Shul'govskaia (?). The book was put out with the inscription "Published by women-translators"; it was a complete success with both readers and critics (Stasov 1899: 131). In the following years, SWT translated several educational and scientific works on history and natural sciences (Stasov 1899: 137-138). SWT was quick to translate and publish the most prominent scientific books published in Europe. In the mid-1860s, Darwin's discoveries were widely discussed in Russia. The well-known professor of law Petr Redkin recommended Stasova to translate and publish Henry W. Bates' The Naturalist on the River Amazons as soon as possible. Soon SWT published the book in the translation made by A. Shul'govskaia, Ms. Schul'z (?), Munsh (?) and Babkina (?), the general editor being Stasova (Stasov 1899: 139-140). Administratively, the repertoire of translations was decided by a committee (Stasov 1899: 143). The committee also distributed work among translators.

Despite its relatively short history, SWT was an important milestone in the process of involving women into translation work: women-translators became socially prominent as an organization. Never again in Russian history women established any organization where translation would be made by a team of women on such scale. Women worked as translators in publishing houses or in mass media; they formed teams (not necessarily composed only of women), like Sof'ia Parnok(h) (1885-1933), who paired up with other translators, or like Adelaida (1874-1925) and Evgeniia (1878-1944) Gertsyk; but never was there an all-women publishing house putting out translations almost exclusively. 
A remarkable achievement of women in the period of the Great Reforms is the work as publishers of translations. Elizaveta Akhmatova (1820-1904) was a translator but also a pioneer in assuming the responsibility of the editorin-chief and publisher. She founded her journal A Collection of Foreign Novels and Stories Translated into Russian in 1856 and published as many as 344 issues over the period of thirty years. She published over 300 translated works by French and English writers.

Aleksandra Kalmykova (1849-1926) took part in the work of Petersburg Literacy Committee in the 1880s. Although the majority of publications under the aegis of the Committee were Russian literature, there were also translations of Dickens, Defoe, Hugo, Zola and George Sand. Later, Kalmykova opened her own book-selling enterprise promoting translations of works by Scott, Dickens, Andersen (Liublinskii 1988: 46, 49). Ol'ga Popova (18481907) translated works by the Swiss pedagogue Pestalozzi (ibid.: 67). Together with her husband, Aleksandr Popov, she published the journal Upbringing and Education where she invited other women-translators to contribute. In another journal, The New Word, which Popova owned in 1895-1897, she published and possibly edited translations of a number of Western European contemporary writers. Incidentally, Popova was among the first to publish translations of works by Marx, Engels and Paul Lafargue in Russia (ibid.: 73, 75). Beside her journals, Popova published contemporary scientific works and political and economic literature.

\section{Pre-Soviet, Soviet and Post-Soviet Periods}

\subsection{The Silver Age and After}

In the twentieth century, as before, women-translators participated in all major literary and social processes involving translation. They shared all the advantages and disadvantages of the vicissitudes of life in twentieth-century Russia and the Soviet Union. In the literary domain, women-translators contributed to establishing the Silver Age of Russian literature. Russia's Golden Age, the time of flourishing of young Russian literature and especially poetry, had been in the early nineteenth century. The term "Silver Age" was coined in reference to the Golden Age, associated with such names as Pushkin, Baratynskii, Lermontov, etc. Both epochs thrived on translation. Women-translators' role in both Golden and Silver Ages as well as in the period of great Russian prose of the late-nineteenth century is understudied. As far as the Silver Age is concerned, such women-translators as Anastasiia Chebotarevskaia (18761921), who translated French and German authors (in collaboration with 
her husband, the well-known Russian writer Fedor Sologub), and Liudmila Vil'kina (Izabella Vil'ken, 1873-1920), with her translation of Maeterlinck's plays, undertaken together with her husband, the poet Nikolai Minskii, contributed to one of the major Silver Age literary trends, Symbolism. G. Galina (Glafira Mamoshina, 1873-1942) translated the "godfather of modern drama" Henrik Ibsen. Anna Ganzen (née Vasil'eva, 1869-1942), who collaborated with her husband, Petr Ganzen, translated many Scandinavian authors.

As before, in the eighteenth century, women popularized Russian literature abroad: for example, Anna Avinova (1869-1935, pseudonym: Ivan Strannik) published a collection of the well-known proletarian writer Maksim Gor'kii's stories in French (1903).

The Soviet regime marked a major rupture in Russian history. Many prerevolutionary publishing institutions suddenly ceased to exist. The Bolsheviks established strict control over publishing, the content and the circulation of publications, including translations (Nazarov 1964: 22; Dinershtein and Gol'tseva 1978: 130-186). Eventually the new regime re-established the interrupted communication with the rest of the world, especially with Western Europe. In 1920, projects of (re)translating world classics and contemporary literary works of writers sympathizing with the new regime were launched. The absolute majority of employed translators had received education before the revolution, because few proletarians were equipped with the necessary knowledge and skills. Educated women's command of foreign languages came in handy again. ${ }^{19}$ For many of these women, translation provided salvation under the heavy post-revolutionary proletarian ideological pressure; for some, it was literally the only way to survive by earning some kind of living. In later periods of Soviet history, translation continued to be salvation from the Soviet regime in its Leninist-Stalinist or milder Khrushchev-Brezhnev versions.

Anna Akhmatova (1889-1966) had become famous in pre-revolutionary Russia. Her relationship with the Soviet establishment was very dramatic. She was considered a "relic" of the past and her poetry after 1917 remained largely unpublished. Later, she was accepted to the Union of (Soviet) Writers, only to be soon expelled. Her son Lev was twice imprisoned as a sign to Akhmatova that she should be more cooperative with the Soviet regime. During these years her only way to make living was by translation. She translated halfheartedly, though, because, reportedly, she was skeptical about the possibilities to translate poetry.

19. Many women, some of them representatives of the nobility, were tolerated by the regime as "fellow-travellers" (cf. Dinershtein and Gol'tseva 1978: 194). 
Marina Tsvetaeva (1892-1941) had also made a name for herself before the Bolshevik revolution, after which she left Russia. In 1939, however, she returned to the USSR. As is clear from her correspondence with the Secretary of the Writers' Union, Aleksandr Fadeev, Tsvetaeva was ready to live largely from translation. Yet her translation work took a morbid turn: very soon she was doomed to translate from any language and very often from poorly made interlinear versions.

Another poet of the same pleiad, Sof'ia Parnok, also had to scrape a living doing team translations from French and German literature (LRZ: 486). Akhmatova, Tsvetaeva and Parnok were among the most well known womenwriters who translated not necessarily because they chose to. To be sure, there were many less known women forced to share the same destiny. To emphasize, this destiny was not exclusively women's. For example, Boris Pasternak had to resort to translation when his own work was out of favor in the 1930s.

Tat'iana Shchepkina-Kupernik (1874-1952), however, belonged to a different group of women-translators of the early Soviet period. She was primarily a translator and contributed greatly to both pre-Soviet and Soviet periods of Russian literary history by her versions of dramatic classics, such as Rostand, Molière and Shakespeare. Yet there was "a more personal motivation for this work, as we know by her own account that it served her as a means of escape from her environment, both in space and in time" (LRZ: 584). The translator's career often was a form of escapism in the harsh Soviet years.

Anna Akhmatova wittily called the post-Stalinist Soviet history "vegetarian" because the Communist Moloch stopped requiring human sacrifices: dissidents were incarcerated, sent to mental institutions or exiled from the country, but not killed anymore. The ideological press, however, remained and women-writers continued to translate. Yet they translated not always in order to survive or escape the grim reality, but of their own accord. The ratio of those being forced to translate and translating of one's own good will in any period does not lend itself to the simplistic "either/or." Rather, it is a matter of degrees. Yet in early Soviet Russia, as compared to the Russia after Stalin, translation was more often than not the only way to withstand the hardships. Bella Akhmadulina's case (b. 1937) provides a good example. Her original poetry of the early post-Stalinist period of Soviet history (after 1953) was criticized by the Communist party and eventually she was expelled from the Union of Writers. Yet she was welcomed back as a translator. Margarita Aliger (1915-1992) also débuted as translator, being already a mature poet and writer, with her book The Huge World (1968) including translations from French, Italian and the languages of Latin America. In contrast to Akhmadulina, 
Aliger's translation work was not any form of salvation or escapism because both her original works and translations well complied with Soviet ideology.

\subsection{Literary Projects, Journals and Publishing Houses}

Для полного освобождения женщины и для действительного равенства ее с мужчиной нужно, чтобы было общественное хозяйство и чтобы женщина участвовала в общем производительном труде. ${ }^{20}$

Vladimir Lenin, 1919

In Soviet Russia, education became accessible to all. Women became more prominent on the social arena, many as translators/interpreters. Individualism was not encouraged and translators had to work as members of various organizations-trade unions, publishing houses, translation bureaus. Even literary translation was commissioned to members of the Unions of Writers and Translators. No translation could be published without an official imprimatur.

In 1918 in Petrograd, on the initiative of Maksim Gor'kii, the state publishing house World Literature was set up. The goal was to translate or retranslate classics of world literature as well as to ensure the high quality of translations and compliance with the proletarian ideology. Another lofty goal that Gor'kii had set for himself was to employ and literally save the prerevolutionary intelligentsia. Some hundred people started working in the publishing house, among whom there were women-translators, such as Dora Leikhtenbergskaia (1870-1937), S. Sviridenko (Sofiia Sviridova, 1882-?, see Ginzburg 2004), Anna Ganzen, Ekaterina Sultanova (née Letkova, 1856-1937), Zinaida Zhuravskaia (née Lashkevich, 1867-1937), Tat'iana Klado (1889-1972) and others. Academia (1922-1937) was another influential publishing house where many women-translators worked, the best known of whom is Anna Radlova (1891-1949) (Krylov and Kichatova 2004). Later, women-translators collaborated in other publishing houses specializing in translation, notably Rainbow.

Translation work also continued among the Russian émigré community. Nina Berberova (1901-1993) and Mariia Olsuf'eva (1907-1988) were less known, if at all, in the Soviet Union, yet they brought Russian and Soviet

20. In order to free woman fully and make her truly equal with man, the common social economy is required and woman should participate in the common productive work. 
literature to foreign readers. Gizella Lakhman (1895-1969) was a minor émigré poet of the Silver Age. In her emigration, she published translations of Emily Dickinson and Robert Frost's poetry in various Russian émigré journals. Today, in the post-Soviet era, this tradition continues and some women translate from the country to which they have immigrated. Recently, Liudmila Pruzhanskaia as editor and translator compiled an entire issue of the journal Foreign Literature (2008, No. 11) devoted to translations of Québecois authors.

A characteristic feature of literary translation of the twentieth century is a high degree of source language/culture specialization of women-translators. An important part of these specializations is non-Western European and ancient languages, such as Japanese, Hebrew, Persian, Sumer and Akkad. Many more names may be found on official sites of journals and publishers, for example: http://www.inostranka.ru/ru/translators/.

\subsection{Beyond Written Translation}

Literary translation was not the only domain where women-translators worked. Women-translators were employed in translation bureaus, for example The Russian Translation Centre (Moscow). After the perestroika (1986), a number of such translation bureaus mushroomed because many Russian organizations started operating internationally. Special research would need to be conducted in order to gauge the participation of women in all these organizations and processes. One can, however, be sure that a great number of women worked and still work as translators. This is clear even from the fact that the majority of students of foreign language and translation departments at Soviet and post-Soviet universities were and still are women. The tradition of women studying foreign languages, although significantly diminished, still lives on.

In Soviet times, women often worked as interpreters. To give only one example, Mariia Zakrevskaia's life story is amazing and has its mysterious turns (Budberg, 1892-1974). In the 1920s, she worked as H. G. Wells' official interpreter during his visit in the USSR.

In 2000, Margarita Nerucheva was a Soviet interpreter who served at Spandau prison after WWII where Nazi criminals were kept. Although her memoirs only contain several pages about her work and training as translator (2000: 116, 135, 140), otherwise being of general historical interest, they constitute a valuable testimony of women's involvement as translators/interpreters in key social historical events of the twentieth century. 
Before concluding, I would like to mention yet another translation-related involvement of women-training younger generations of translators. For example, Nina Zhirmunskaia (1919-1991) was both a scholar and translator. She also supervised work of young translators. Since the establishment of translation studies as a scholarly discipline, women have not only been taught translation but teach it as well. A significant number of publications in translation studies are written by women-scholars. The translator/editor Nora Gal' (1912-1991) wrote a book on literary translation, The Word Living or Dead. Since the first edition in 1972, the book went through several editions. Tsvetaeva, Akhmadulina, Nina Demurova, Ol'ga Kholmskaia, Vera Markova, to name just a few, also published articles discussing various aspects of literary translation. In the two major translation journals, Mastery of Translation and The Translator's Notes, many other women-scholars published their contributions.

\section{Conclusion}

My analysis shows that in Russian translation history women did not form a separate and closed part of the translation social structure. As both male and female gametes blend in the egg, so too do communications passing through both men and women blend in the translation system. If one pushes the separation of men and women too far, one's logic starts to collapse. At one instant this is what seems to happen in Rosslyn (2000):

Women translators found themselves in a different situation from their male counterparts. They had no opportunity to enter state service as translators or to participate in the various translators' societies. Most had no contact with literary circles. Most were inexperienced as writers, and, because they were women, had to combat prejudices against their writing, prove their competence and claim their place in literary life. But their status as casual amateurs was shared by most men who translated at this time (p. 169; emphasis in both cases is added-S.T.)

The paragraph finishes with a statement contradicting its beginning. The line separating female and male translators seems to be drawn too sharply. Women-translators did not constitute a uniform social body; nor did mentranslators. Clearly, women differed from men in that they could not enter state service as translators, but one cannot be so sure about the rest of the listed differences.

I have concentrated on women's role in the translation social structure and activity. Women participated in all major acts of exchange between the social system and its environment. Since as a social system in Luhmannian 
sense (Tyulenev 2009b), eighteenth-century Russia opened to its Western environment onwards, women's participation in their capacity as translators / interpreters and educators of translation grew considerably. From the outset, the westernization of Russia was carried out through translation, and womentranslators contributed a great deal. Women-translators either took part in introducing new communication phenomena into the system or reinforced what had been introduced by their male colleagues. To emphasize, the separation of translation history into male and female parts is artificial and justifiable only in order to recover women's contribution. As we have seen, women exercised their role of translators in the same spheres as men did: they translated both literary and non-literary texts, they transferred knowledge from outside into Russia and thereby re-negotiated the dominant social-ideological discourse.

\section{References}

ANDREW, Joe. (2001) “'A Crocodile in Flannel or a Dancing Monkey': the Image of the Russian Woman Writer, 1790-1875". In: Edmondson, Linda (ed.) Gender in Russian History and Culture. Houndmills, Basingstoke, Hampshire: Palgrave. pp. 52-72.

Aristarkhova Irina. (1995) "Controlling Women, Controlling Men": Popular Conceptions of Gender Relations in the Middle Ages in England. Coventry: University of Warwick, Centre for Comparative Labour Studies, No. 6.

ARLOU UladzimiR. (1998) Zhyvatvorny simval Bats'kaushchyny: Gistoryia Kryzha sviatoi Eufrasinni Polatskai [Life-giving Symbol of Motherland: The History of Saint Evfrosiniia of Polotsk]. Minsk: Asar.

BARENBAUM, I. (1995) "Zhenshchiny v demokraticheskom knizhnom dele 60-70kh godov XIX veka" [Women in the Democratic Publishing Business in the 1860s-1870s]. In: Tishkin, G. Feminizm i rossiiskaia kultura [Feminism and Russian Culture]. Saint-Petersburg: n/e. pp. 51-60.

BISHA, Robin; Jehanne M Gheith; Christine Holden \& William G. Wagner (eds.) (2002) Russian Women, 1698-1917: Experience and Expression, An Anthology of Sources. Bloomington \& Indianapolis: Indiana University Press.

BoshKovsKA, Nada. (2008) "Pravovoe polozhenie zhenishchiny v Rossii v XVII veke" [The Legal Rights of Women in Russia in the Seventeenth Century]. In: Pushkareva Natal'ia (ed.) Gendernoe ravnopravie v Rossii [Gender Equality in Russia]. Saint-Petersburg: Aleteiia. pp. 33-37.

BukHSHTAB, B. (ed.) (1972) Russkaie poety 1840-1850-kh godov [Russian Poets of the 1840s-1850s]. Leningrad: Sovetskii pisatel'.

Celano, Thomas of. (2000) First life of St Francis of Assisi. Translated by Christopher Stace. London: Triangle. 
Clements, Barbara Evans; Barbara Alpern Engel \& Christine Worobec (eds.) (1994) Russia's Women: Accommodation, Resistance, Transformation. Berkeley $\&$ Los Angeles: University of California Press.

Dashkova SPbGU. http://www3.spbu.ru/History/275/Chronicle/pu/Persons/D_ ashkova.html. (Accessed on December 14, 2009)

Delboulle, A. (1891) Anacréon et les poèmes anacréontiques. Texte grec avec les tracutions et imitations des poètes $d u X V I^{e}$ siècle. Havre: Lemale et $C^{i e}$, Imprimeurs éditeurs.

DenBeste, Michelle. (2008) "Women in the Professions in Russia at the End of the Nineteenth Century". In: Pushkareva, Natal'ia (ed.) Gendernoe ravnopravie $v$ Rossii [Gender Equality in Russia]. Saint-Petersburg: Aleteiia. pp. 87-95.

DinERSHTEIN, Efim \& Era Gol'tseva. (1978) Izdatel'skoe delo v SSSR. (1923-1931) [Publishing in USSR. (1923-1931)]. Moscow: Kniga.

Even-ZOHAR, Itamar (ed.) (1990) "Polysystem Studies." Special issue of Poetics Today, Vol. 11, No. 1.

Evfrosinila. (2006) Prepodobnaia Evfrosiniia, kniazhna i igumeniia Polotskaia [St Evfrosiniia of Polotsk]. Minsk: Pravoslavnoe bratstvo v chest' Sviatogo Arkhistratiga Mikhaila.

FOERSTER, Heinz von. (1981) Observing Systems. Seaside, California: Intersystems Publications.

GINZBURG, Grigorii. (2004) O poetesse-perevodchitse pod psevdonimom S. Sviridenko [About the Woman Poet and Translator under the Pseudonym S. Sviridenko]. http://www.proza.ru/2004/03/01-09. (Accessed on January 28, 2010)

GOEPFERT, Frank. (1995) "Zametki o dramaturgii E. R. Dashkovoi" [Notes concerning Ekaterina Dashkova's Plays]. In: Tishkin, G. Feminizm i rossiiskaia kul'tura [Feminism and Russian Culture]. Saint-Petersburg: n/e. pp. 112-117.

GOEPFERT, Frank \& Mikhail Fainshtein (eds.) (1998) Predstatel'nitsy muz: russkie poetessy XVIII veka [Eighteenth-Century Russian Women Poets]. Wilhelshorst: Verlag F.K. Goepfert.

GOEPFERT, Frank \& Mikhail Fainshtein (eds.) (1999) My blagodarny liubeznoi sochinitel'nitse...: proza i perevody russkikh pisatel'nits kontsa XVIII veka [Prose and Translations by Russian Women of the Late Eighteenth Century]. Fichtenwalde: Verlag F.K. Goepfert.

GOEPFERT, Frank. (2003) "Observations on the Life and Work of Elizaveta Kheraskova. (1737-1809)". In: Rosslyn, Wendy. Women and Gender in $18^{\text {th }}$ Century Russia. Aldershot, Hampshire: Ashgate. pp. 163-186.

GuKOVSKII, Grigorii. (1927) Russkaia poeziia XVIII veka [Russian Poetry of the Eighteenth Century]. Leningrad: Academia. [Reprint: 1971. "Journalfranz" Arnulf Liebing, oHG - Wuerzburg.] 
HammarberG, Gitta. (2003) "Women, Critics, and Women Critics in Early Russian Women's Journals". In: Rosslyn, Wendy. Women and Gender in $18^{\text {th }}$-Century Russia. Aldershot, Hampshire: Ashgate. pp. 187-207.

HAMmARBERG, Gitta. (2007) "The First Russian Women's Journals and the Construction of the Reader". In: Rosslyn, Wendy \& Alessandra Tosi (eds.) Women in Russian Culture and Society, 1700-1825. Houndmills, Basingstoke, Hampshire: Palgrave Macmillan. pp. 83-104.

KalinNiKOv, Pavel. (1997-2009) Russkii biograficheskii slovar'. Setevaia versiia. [Russian Biographical Dictionary. An Internet Version]. http://rulex.ru/. (Accessed in November-December 2009)

Kelly, Catriona. (2002) "Sappho, Corinna, and Niobe: genres and personae in Russian women's writing, 1760-1820”. In: Barker, Adele M. \& Jehanne M Gheith (eds.) A History of Women's Writing in Russia. Cambridge: Cambridge University Press. pp. 37-61.

KOMAROV, Vitalii \& Iraida Komarova. (1997-2004) Istoriia russkoi kul'tury [A History of Russian Culture]. (Based on a compilation of pre-revolutionary dictionaries) http://www.vitart.ru/history-russia-culture-pages/article-iskusstvoteatr.html. (Accessed on December 3, 2009).

KRYLOV, Viatcheslav \& Iekaterina Kichatova. (2004) Izdatel'stvo "Academia": Liudi i knigi. 1921-1938-1991 [The Publishing House "Academia": People and Books. 1921-1938-1991]. Moscow: Academia.

LEVENTER Herbert Michael. (1972) Tatishchev: Science and Service in Eighteenth Century Russia. Manuscript of the Ph.D. thesis. Columbia University. Ann Arbor: Xerox University Microfilms.

LIKHACHEVA, Elena. (1890) Materialy dlia istorii zhenskogo obrazovaniia v Rossii. (1086-1796) Saint-Petersburg: Tipografiia Stasiulevicha.

LiUblinSKII, Sergei. (1988) Podvizhniki knigi [Devotees of Book]. Moscow: Kniga.

LRZ: LedKOvSKY, Marina; Charlotte Rosenthal \& Mary Zirin (eds.) (1994) Dictionary of Russian Women Writers. Westport, Connecticut, London: Greenwood Press.

MCKenZIE, Rosalind. (2002) "Women's image in Russian medieval literature". In: Barker, Adele M. \& Jehanne M Gheith (eds.) A History of Women's Writing in Russia. Cambridge: Cambridge University Press. pp. 16-35.

Mel'Nikov, Aleksei. (1997) Prepodobnaia Evfrosiniia Polotskaia [St. Evfrosiniia of Polotsk]. Minsk: Chetyre chetverti.

MOKUL'SKII, Stefan. (1929-1939) "Molière". In: Literaturnaia Entsiklopediia [Literary Encyclopaedia]. Moscow: Izd-vo Kom. Akad. http://feb-web.ru/feb/ litenc/encyclop/. (Accessed on December 3, 2009)

NAZAROV, Aleksei (ed.) (1964) Knigoizdatel'stvo v SSSR. (1917-1964) [History of Publishing in the USSR. (1917-1964)]. Moscow: Nauka. 
NikOlaEv, Petr (ed.) (1996 [1926]) Russkie pisateli. XIX vek. Biobibliograficheskii slovar' [Russian Writers. Nineteenth Century. Biobibliographical Dictionary]. $2^{\text {nd }}$ edition. Moscow: Prosveshchenie.

NorTOn, Barbara T. \& Jehanne M Gheith (eds.) (2001) An Improper Profession: Women, Gender, and Journalism in Late Imperial Russia. Durham \& London: Duke University Press.

O’MALley, Lurana Donnels. (2007) "Signs from Empresses and Actresses: Women and Theatre in the Eighteenth Century". In: Rosslyn, Wendy \& Alessandra Tosi (eds.) Women in Russian Culture and Society, 1700-1825. Houndmills, Basingstoke, Hampshire: Palgrave Macmillan. pp. 9-23.

PANCHENKO, Aleksandr (ed.) (1988, 1999) Slovar' russkikh pisatelei XVIII veka [A Dictionary of Russian Writers of the Eighteenth Century]. http://lib. pushkinskijdom.ru/Default.aspx?tabid=460. (Accessed in November-December 2009)

PAVlenKo, Nikolai. (1999) Ekaterina Velikaia [Catherine the Great]. Moscow: Molodaia Gvardiia.

Pavlova, Karolina. (1994) Das Deutsche Werk Karolina Karlovna Pavlovas. Herausgegeben von Frank Goepfert. In three volumes. Potsdam: Universitaet Potsdam.

Pietrow-EnNKer, Bianca. (2005/1999) “Novye liudi” Rossii: Razvitie zhenskogo dvizheniia ot istokov do Oktiabr'skoi revoliutsii [Russlands »neue Menschen«: Die Entwicklung der Frauenbewegung von den Anfaengen bis zur Oktoberrevolution.]. Translated by Iu.P. Shatton. Moscow: RGGU.

Poulton, Leslee. (2002) The Influence of French Language and Culture in the Lives of Eight Women Writers of Russian Heritage. Lewiston, Queenston, Lampeter: The Edwin Mellen Press.

Pushkareva, Natal'ia. (1989) Zhenshchiny Drevnei Rusi [Women of Kievan Rus']. Moscow: Mysl'.

PushkareVA, Natal'ia. (1997) Women in Russian History: From the Tenth to the Twentieth Century. Translated and edited by Eve Levin. Armonk, NY, and London: M.E. Sharpe.

PUSHKAREVA, Natal'ia. (2002) Russkaia zhenshchina: Istoriia i sovremennost'. Dva veka izucheniia "zhenskoi temy" russkoi i zarubezhnoi naukoi. 1800-2000. [Russian Woman: Past and Present. Two Centuries of Women Studies in Russia and Abroad. 1800-2000.] Moscow: Ladomir.

PUSHKAREVA, Natal'ia. (2008) "Zhenskaia i gendernaia istoriia: itogi i perspektivy razvitiia v Rossii" [The History of Women and Genders: Achievements and Perspectives of Development in Russia]. In: Pushkareva, Natal'ia (ed.) Gendernoe ravnopravie v Rossii [Gender Equality in Russia]. Saint-Petersburg: Aleteiia. pp. 223-226. 
Rosenholm, Arja. (2001) "Mariya Vernadskaya: Missionary of 'Scientific Femininity". In: Edmondson, Linda (ed.) Gender in Russian History and Culture. Houndmills, Basingstoke, Hampshire: Palgrave. pp. 73-92.

Rosslyn, Wendy. (2000) Feats of Agreeable Usefulness: Translations by Russian Women 1763-1825. Fichtenwalde: F.K. Goepfert.

RostopchinA, Evdokiia. (1910?) Sobranie sochinenii grafini E.P. Rostopchinoi [Collected Works by Countess Evdokiia Rostopchina]. Saint-Petersburg: Tipografiia A.A. Kaspari.

RULIN, Petr. (1928) Russkie perevody Mol'era v XVIII veke [Russian Translations of Molière in the Eighteenth Century]. (A reprint is available at http://feb-web. ru/feb/izvest/1928/01/281-221.htm; accessed on December 3, 2009)

SAZONOVA, Lidiia. (2002) "Perevodnoi roman v kruge masonskogo chteniia". In: Sakharov, V. (ed.) Masonstvo i russkaia literatura XVIII—nachala XIX vv. [Freemasonry and Russian Literature of the Eighteenth-Early Nineteenth Centuries]. Moscow: Ediotial URSS. pp. 30-52.

SEVCENKO, Ihor (ed.) (1992) The Hagiography of Kievan Rus'. Translated with an Introduction by Paul Hollingsworth. Vol. II. Distributed by Harvard University Press for the Ukrainian Research Institute of Harvard University.

SIDOROV, Aleksei (ed.) (1964) Russkoe knigopechatanie do 1917 goda. (1564-1917) [History of Publishing in Russia. (1564-1917)]. Moscow: Nauka.

Smagina, Galina. (2006) Spodvizhnitsa Velikoi Ekateriny [Great Catherine's Associate]. Saint-Petersburg: Rostok.

STASOv, Vladimir. (1899) Nadezhda Vasil'evna Stasova. Vospominaniia i ocherki. [Nadezhda Stasova. Memoirs and Essays]. Saint-Petersburg: Tipografiia M. Merkusheva.

SvIIASOV, Evgenii. (2003) Safo i russkaia liubovnaia poeziia XVIII-nachala XX vekov [Sappho and Russian Love Poetry of the Eighteenth-Early Nineteenth Centuries]. Saint-Petersburg: Dmitrii Bulanin.

Tosi, Alessandra. (2007) "Women and Literature, Women in Literature: Female Authors of Fiction in the Early Nineteenth Century". In: Rosslyn, Wendy $\&$ Alessandra Tosi (eds.) Women in Russian Culture and Society, 1700-1825. Houndmills, Basingstoke, Hampshire: Palgrave Macmillan. pp. 39-62.

TYULENEV, Sergey. (2009a) "Why (not) Luhmann? On the applicability of social systems theory to translation studies". Translation Studies, Vol. 2, No. 2. pp. 147-162.

TyulEnEV, Sergey. (2009b) "The Meaning Constituting Function of Translation," on the official site of Canadian Association for Translation Studies: http:// www.uottawa.ca/associations/act-cats/Young_Researchers_archive/TyulenevMeaning\%20Constituting\%20Function\%20of\%20Translation.pdf. (Accessed on December 13, 2009). 
UCHENOVA, Viktoriia (ed.) (1989) Tsaritsy muz: russkie poetessy XIX-nachala $X X v v$. [Princesses of Muses: Russian Women-Poets of the Nineteenth-Early Twentieth Centuries]. Moscow: Sovremennik.

VATSURO, Vadim. (2002) Goticheskii roman v Rossii [Gothic Novels in Russia]. Moscow: Novoe literaturnoe obozrenie.

VORONTSOV-DASHKOV, Aleksandr (ed.) (1996) Ekaterina Romanovna Dashkova: Issledovaniia i materialy [Ekaterina Romanovna Dashkova: Research and Documents]. Saint-Petersburg: Dmitrii Bulanov.

VOWLES, Judith. (2002) "The inexperienced muse: Russian women and poetry in the first half of the nineteenth century". In: Barker, Adele M. \& Jehanne M Gheith (eds.) A History of Women's Writing in Russia. Cambridge: Cambridge University Press. pp. 62-84.

WhitTAKer, Cynthia H. (ed.) (2003) Russia Engages the World, 1453-1825. Cambridge, Massachusetts \& London, England: Harvard University Press. 